\title{
PENINGKATAN AKTIVITAS WARGA SEKOLAH DAN PRESTASI SEKOLAH MENUJU SEKOLAH ADIWIYATA DENGAN MENGGUNAKAN PROGRAM JUM'AT BERSIH DI SMP KABUPATEN PATI
}

\author{
Sadiyo
}

\begin{abstract}
The purpose of this research are 1) to increase the activity of school citizen with "Clean Friday" program to be an Adiwiyata school or create the school environment. 2) Increase Adiwiyata school achievement with "Clean Friday" program to be Adiwiyata School high level.

This research is school action research with the technique of the data are document and experiment, that hold from January until May 2015. The object of the research is the school of Pati Principal, especially SMP N 8 Pati, SMP N 7 Pati, and SMP N Gembong. The researcher took that schools because based on the first data supervisi showed bad score.

The activity score and school achievement in cycle I or II took from instrument BLH Pati.The result of the data in cycle I, the activity score of school citizen SMP N 8: 72.7, SMP N $7: 75$, and SMP N Gembong 59. Meanwhile the Adiwiyata School achievement, SMP N 8 :71.5. SMP N 7 : 60.75. SMP N Gembong : 55. In cycle II the activity score of school citizen, SMP N $8: 81$. SMP N 7 : 79,5, and SMP N Gembong 63. And the adiwiyata school achievement, SMP N 8 :74.5. SMP N 7 : 72.25. SMP N Gembong : 67.75 .

Based on the result of the research can concluded that the application of "Clean Friday" program to be Adiwiyata school can increase the score are: the activity of school citizen of SMP N 8 is 8.3 or $11.4 \%$. SMP N 7 is 3.5 or $4.6 \%$ and SMP N Gembong is 3.4 os $5.7 \%$. Meanwhile the adiwiyata school achievement, SMP N 8 is 3.0 or $4.1 \%$. SMP N 7 is 12.5 or $2.05 \%$ and SMP N Gembong is 11.25 or $2.05 \%$.
\end{abstract}

\section{ABSTRAK}

Tujuan penelitian ini adalah: 1. Meningkatkan aktivitas warga sekolah dengan program Jum'at Bersih untuk menuju sekolah adiwiyata atau sekolah berwawasan lingkungan. 2. Meningkatkan prestasi sekolah adiwiyata dengan program Jum'at Bersih untuk menjadi sekolah yang berpridikat adiwiyata yang lebih tinggi.

Penelitian ini adalah penelitian tindakan sekolah dengan menggunakan metade pengumpulan data secara: dokumentasi dan ekperimen, yang dilaksanakan mulai bulan Januari sampai dengan Mei 2015. Obyek penelitiannya adalah sekolah sekabupaten Pati khususnya SMP Negeri 8 Pati, SMP Negeri 7 Pati, dan SMP Negeri Gembong. SMP ini diambil karena dari data hasil supervisi awal menunjukan hasil yang kurang baik

Nilai aktivitas dan prestasi sekolah pada siklus I maupun siklus II diambil dengan intrumen dari BLH Pati.

Hasil pengolahan data. Baik siklus I dan siklus II yang masing masing sudah melaksanakan program Jum'at Bersih dengan hasil sebagai berikut: siklus I nilai aktiviatas warga sekolah, SMP N 8 : 72,7. SMP N 7 : 75, dan SMP N Gembong 59. Sedang nilai prestasi sekolah adiwiyata, SMP N 8 :71,5. SMP N $7: 60,75$. SMP N Gembong : 55. Pada siklus II nilai aktiviatas warga sekolah, SMP N 8 : 81. SMP N $7: 79,5$, dan SMP N Gembong 63. Sedang nilai prestasi sekolah adiwiyata, SMP N 8 :74,5. SMP N $7: 72,25$. SMP N Gembong : 67,75.

Secara keseluruhan hasil penelitian ini dapat disimpulkan bahwa, penerapan program Jum'at Bersih untuk sekolah menuju sekolah adiwiyata secara umum mengalami kenaikan sebagai berikut: Untuk aktivitas warga sekolah SMP N 8 sebesar 8,3 atau 11,4\%. SMP N 7 sebesar 3,5 atau 4,6 \% dan SMP N Gembong sebesar 3,4 atau 5,7 \%. sedangkan untuk prestasi sekolah adiwiyata, SMP N 8 sebesar 3,0 atau 4,1\%. SMP N 7 sebesar 12,5 atau 2,05\% dan SMP N Gembong sebesar 11,25 atau $2,05 \%$. Dibandingkan dengan kondisi awal.

Kata Kunci: Aktivitas, Prestasi warga sekolah, Program jum'at bersih. 


\section{A. Latar Belakang Masalah}

Sekolah merupakan suatu lembaga sebagai pusat budaya, pusat informasi, pusat ilmu pengetahuan, maka sekolah harus dikondisikan selalu bersih, nyaman, rindang, sejuk, damai, dan asri atau sekolah berbudaya lingkungan. Agar semua warga sekolah dapat nyaman untuk belajar dan bekerja menjalankan kuwajibannya masing-masing. Hal ini bisa tercipta apabila kesadaran masyarakat sekolah akan arti kebersihan dan kerindangan sekolah menjadi suatu hal yang biasa dan suatu kebutuhan dalam hidup.. Lingkungan yang asri adalah lingkungan yang kondisinya bersih, rindang dan banyak ditumbuhi tanaman yang terawat secara baik dan teratur.

SMP di kabupaten Pati pada dasarnya secara tradisional sudah banyak yang telah mengkondisikan lingkungan sekolahnya menjadi sekolah yang asri, dan nyaman. Namun belum membiasakan melibatkan seluruh warga sekolah menjadi pelaku secara keseluruhan atau totalitas, warga sekolah bertindak sendirisendiri dengan cara siswa melaksanakan kebersihan kelas setiap mau memulai pelajaran, tukang kebun melaksanakan kebersihan pada saat kebunnya sudah rungkut, atau dengan kata lain masing-masing warga sekolah berjalan sendiri dan tidak terprogram. Sehingga kondisi sekolah kurang dapat membuat nyaman warga sekolahnya. Hal semacam ini perlu adanya cara atau wadah yang dapat membuat sekolah tersebut menjadi sekolah yang asri, nyaman, dan menyenangkan bagi warga sekolahnya. Dengan kata lain sekolah dikabupaten Pati yang mendapat sebutan sekolah adiwiyata tingkat nasional hanya satu yaitu SMP Negeri 1 Jakenan. Sehingga perlu adanya gebrakan untuk mendorong sekolah berlomba-lomba membuat program untuk menjadikan sekolah adiwiyata. program yang akan diterapkan adalah program Juma't Bersih yaitu program yang didalamnya berisi program : kerja bakti, pemilahan sampah, komposter, biofori, bank sampah, pembuatan ipal, kantin ramah lingkungan, penghijauan, 3R, Toga, aqua ponik, green hous, dan sel surya.

Dari pantauan dan pengematan selama satu tahun sekolah SMP dikabupaten Pati banyak yang belum memiliki kebiasaan hidup bersih atau hidup sehat secara teratur dan berkesinambungan secara terus menerus atau sekolah yang berbudaya lingkungan, sehingga kekurang pedulian warga sekolah terhadap kebersihan lingkungan tidak terjamin, lebihlebih terhadap kerindangan lingkungan sekolah khususnya dan lingkungan masyarakat pada umumnya. Hal ini telah dibuktikan dari 49 sekolah SMP negeri hanya satu SMP yang menjadi sekolah adiwinyata tingkat nasional yaitu SMP 1 Jakenan, dan satu sekolah adiwiyata tingkat propinsi yaitu SMP Negeri 3 Pati. Peneliti sebagai pengawas sekolah bekerja sama dengan BLH (badan lingkungan hidup), dan atas ijin dari bapak kepala Dinas Pendidikan Kabupaten Pati untuk memotifasi sekolah-sekolah agar aktifitas warga sekolah lebih bergairah untuk menuju sekolah yang berwawasan lingkungan atau sekolah adiwiyata dengan program Juma't Bersih.

Sedangkan sekolah yang akan diberi tindakan adalah SMP Negeri 8 Pati, SMP Negeri 7 Pati, SMP Negeri Gembong, ini diberikan tindakan karena sekolah tersebut dengan kondisi sebagai berikut:

Tabel Daftar Sekolah Tempat Penelitian

\begin{tabular}{|c|c|c|c|}
\hline \multirow[t]{2}{*}{ Nama Sekolah } & \multicolumn{3}{|c|}{ Kondisi Awal } \\
\hline & $\begin{array}{l}\text { Aktivitas } \\
\text { Sekolah }\end{array}$ & Warga & $\begin{array}{l}\text { Prestasi } \\
\text { Adiwiyata }\end{array}$ \\
\hline SMP Negeri 8 Pati & 70 & & 69 \\
\hline SMP Negeri 7 Pati & 69 & & 59 \\
\hline SMP N Gembong Pati & 66 & & 55 \\
\hline
\end{tabular}


Dari tiga sekolahan ini khusus SMP Negeri 8 pernah masuk sekolah adiwiyata tingkat jawa tengah, tetapi pemeliharaan sarananya adiwiyata menurun, sehingga perlu dimotifasi lagi.

Dari keadaan lingkungan sekolah yang kurang nyaman dan rindang maka pengawas memberi motifasi kepada warga sekolah untuk peduli dengan lingkungannya, atau memberikan pendidikan cinta lingkungan, lingkungan yang diinginkan adalah lingkungan yang bersih, rindang dengan penghijauan sehingga membuat nyaman warga sekolah yang menempatinya. Maka untuk mencapai cita-cita itu perlu dibuat rencana dengan program Jum'at Bersih yaitu suatu program yang mendorong warga sekolah untuk membiasakan diri dengan kegiata misalnya: Kerja bakti, pemilahan sampah, pembuatan bank sampah, biofori, komposterisasi, green haus, TOGA, akuaponik, dan IPAL. Sedangkan untuk kantin sekolah warganya dibiasakan tidak menggunakan MSG, plastik, zat pengawet, dan makanan disajikan tidak dengan sterefom atau plastik melainkan dengan gelas dan piring.

Dari keadaaan sekolah yang pada umumnya kurang memperhatikah kebersihan yang berwawasan lingkungan dengan banyak tanaman yang menunjang kenyamaan, kesejukan dan keindahan maka dimunculkan program Jum'at Bersih. Program Jum'at Bersih adalah program kerja yang diharapkan mampu untuk meningkatkan kesadaran warga sekolah agar mampu mewujutkan sekolah yang berpridikat adiwiyata. Dengan program Jum'at Bersih ini diharapkan semua siswa, guru, tata usaha dan dimonitoring oleh kader adiwiyata yang ada disekolahan Program Jum'at Bersih ini dimotifasi oleh tenaga ahli lingkungan hidup, sedangkan aktifitas dilakukan oleh seluruh warga sekolah melalui program juma't bersih yang dilakukan setiap hari juma' at secara kontinue. Program-program tersebut tercantum dalam tujuan KTSP dan silabus yang kemudian dioperasionalkan dalam RPP.

Tujuan KTSP adalah menjamin tercapainya tujuan pendidikan nasional, pengembangan sistim penilaian pada KTSP selalu mengacu pada standart kompetensi, kopetensi dasar dan materi pembelajaran yang terdapat pada silabus. Mulyana (2006 : 190) menjelaskan silabus adalah rencana pembelajaran pada suatu kelompok mata pelajaran dengan tema tertentu yang mencakup standart kompetensi, kompetensi dasar, materi pelajaran, indikator, penilaian, alokasi waktu, sumber belajar dan dikembangkan dalam satuan pendidikan.

B. Rumusan Masalah.

Dari latar belakang masalah diatas maka perlu dirumuskan permasalahan sebagai berikut :

1. Apakah program Jum'at bersih dapat meningkatkan aktivitas warga sekolah dalam mendukung sekolah adiwiyata Atau Sekolah Berwawasan Lingkungan.

2. Apakah program Jum'at bersih dapat meningkatkan prestasi sekolah menuju sekolah adiwiyata.

C. Tujuan Penelitian.

Penelitian ini dengan tujuan:

1. Meningkatkan aktifitas warga sekolah dengan program Jum,at Bersih untuk menuju sekolah adiwiyata atau sekolah yang berwawasan lingkungan.

2. Meningkatkan prestasi sekolah adiwiyata dengan program Jum.at bersih untuk menjadi sekolah yang bepridikat adiwiyata yang lebih tinggi.

D. Manfaat Penelitian

Dari penelitian ini diharapkan dapat bermanfaat baik secara praktis, manfaat teoritis yang diharapakan dalam penelitian ini adalah untuk menambah khazanah pengetahuan menajemen sekolah terkait pengelolaan lingkungan. Sedangakan secara teoritis yang diharapkan dalam penelitian ini adalah:

1. Untuk siswa akan terbiasa hidup bersih berwawasan lingkungan.

2. Untuk sekolah mempunyai lingkungan yang bersih, terawat, sehingga akan menambah kenyamanan warga sekolah.

3. Untuk peneliti sebagai pengawas dapat menggeneralisasi ke sekolah yang lain sehingga akan tumbuh sekolah-sekolah yang menuju sekolah adiwiyata yang lebih tinggi.

\section{A. Landasan teori.}

1. Pengertian Belajar.

Belajar merupakan suatu proses yang terjadi dalam diri menusia yang dapat mengubah prilaku manusia itu sendiri. Prilaku itu meliputi: berpikir, berbuat, dan bersikap. Manusia baru bisa dikatakan belajar bila ada perubahan prilaku dari manusia itu sendiri, maka bila tidak ada perubahan prilaku menusia itu tidak dikatakan belajar. Sedangkan menurut teori kontruktivisme yang juga mendasari teori kooperatif dan kognitif menyatakan:"Belajar merupakan proses terpadu yang berlangsung di dalam diri seseorang" (Asra M. Ed 2007: 47). Dari pendapat Asra tersebut maka sekolah 
sebagai stekholden secara terpadu antara siswa, guru, kepala sekolah dan tenaga kependidikan bersatu padu melaksanakan proses untuk menuju pembangunan lingkungan atau sekolah adiwiyata yang telah diinginkan.

Sedangkan belajar menurut Skiner (1958) belajar didefinisikan sebagai berikut "learning is process of progressive bihavior adaptation" belajar adalah suatu proses adaptasi yang bersifat progresif. Maka seseorang dikatakan belajar apabila prilakunya berubah, dari sini maka perlunya suatu stekholden untuk mengubah prilaku dari seluruh anggota masyarakat dalam meningkatkan kinerja untuk meningkatkan pembangunan lingkungan atau meningkatkan status sekalah adiwiyata yang lebih tinggi.

2. Pengertian Adiwiyata.

Adiwiyata bermakna sebagai tempat yang baik dan idial dimana dapat diperoleh segala ilmu pengetahuan dan berbagai norma secara etika yang menjadi dasar manusia hidup menuju kesejahteraan hidup (Dwiyatmo. 2007: 18). Dari dasar diatas maka sekolah adiwiyata dapat dimaknai sekolah yang diciptakan atau mengkondisikan sebagai lingkungan untuk mendorong demi terciptanya lingkungan sekolah yang nyaman, sejuk, dan asri yang cocok untuk lingkungan proses belajar mengajar.

Penerapan prinsip dasar sekolah adiwiyata yaitu: partisipatif, dimana komonitas sekolah terlibat dalam manajemen sekolah yang meliputi keseluruhan proses perencanaan, pelaksanaan, dan evaluasi sesui tanggungjawab dan peran serta berkelanjutan, dimana seluruh kegiatan harus secara terus menerus secara komperensif (Morgan 2009:42).

Sedangkan menurut (Purwodarminto ) dalam kamus bahasa Indonesia sekolah adiwiyata adalah sekolah yang peduli lingkungan yang sehat, bersih, serta loingkungan yang indah. Dengan adanya sekolah adiwiyata diharapkan semua warga sekolah dan lingkungannya dapat menyadari bahwa lingkungan yang hijau adalah lingkungan yang sehat bagi tubuh kita. Adiwiyata berasal dari dua kata yaitu adi dan winyata. Adi sendiri mempunyai arti besar, agung, baik, idial atau sempurna. Sedangkan wiyata mempunyai arti tempat dimana seseorang mendapatkan ilmu pengetahuan, sehingga adiwiyata mempunyai arti tempat yang agung dimana seseorang dapat menimba ilmu pengetahuan.

3. Tujuan Adiwiyata.
Tujuan umum dari sekolah adiwiyata adalah membentuk sekolah yang peduli dan berbudaya lingkungan yang mampu berpartisipasi dan melaksanakan upaya pelestarian lingkungan dan pembangunan berkejutan bagi kepentingan generasi sekarang maupun yang akan datang. Sedangkan tujuan khususnya adalah mewujutkan warga sekolah yang bertanggungjawab dalam upaya perlindungan dan pengelolaan lingkungan melalui tata kelola sekolah yang baik untuk mendukung pembangunan berkelanjutan, dengan prinsip partisipasif dan berkelanjutan. Prinsip partisipatif adalah komonitas sekolah terlibat dalam menajemen sekolah yang meliputi seluruh proses perencanaan, pelaksanaan, dan evaluasi sesuai dengan tanggungjawab dan perannya, sedangkan prinsip berkelanjutan adalah seluruh kegiatan harus dilaksanakan secara terencana dan terus menerus secara komprehensif, kedua prinsip tersebut adalah untuk mencapai sekolah adiwiyata atau sekolah yang berwawasan lingkungan.

Untuk mencapai sasaran sekolah adiwiyata perlu ditetapkan empat komponen adiwiyata, empat komponen tersebut adalah: 1 . Kebijakan berwawasan lingkungan, 2. Pelaksanaan kurikulum berbasis lingkungan, 3. Kegiatan lingkungan berbasis partisipatif, dan 4. Pengelolaan sarana pendukung ramah lingkungan (BLH 2014) dari hal tersebut maka peneliti sebagai pengawas selalu menekankan segala sesuatu kegiatan yang berada di sekolah harus berbasis lingkungan, mulai dari pembuatan APBS (anggaran pendapatan dan belaja sekolah) khususnya pada bagian sarana prasarana, KTSP (kurikulum tingkat satuan pendidikan) khususnya pada visi dan misi, silabus, dan RPP (rencana pelaksanaan pembelajaran), hal tersebut dapat diakses dengan supervisi menejerial dan supervifi akademik.

Supervisi manajerial yang meliputi analisis APBS, KTSP, pada APBS diisaratkan dalam pembuatannya mengalokasikan dana untuk sarana prasarana khusunya untuk biaya ramah lingkungan sebesar $20 \%$ dari seluruh dana yang dianggarakan di sekolah. Sedangka untuk KTSP diharapkan pada visi dan misinya mencamtumkan pembangunan lingkungan, apabila pada visi belum ada atau sudah terlajur jadi maka dapat ditambahkan pada misi sekolah yang tercamtum di KTSP.

Supervisi akademik, pada supervisi ini dilakukan untuk memastika bahwa pada silabus dan RPP telah dicamtumkan tentang adanya 
misi untuk membangun lingkungan, pada silabus bisa disisipka pada pelajaran IPA, Bahasa, PKn, IPS, dan Agama. Begitu juga pada RPP dapat disipkan pada Indikator dan tujuan pembelajaran pada masing-masing mata pelajaran.

4. Pengertian Program Jum'at Bersih.

Jumat Bersih adalah suatu program gerakan kebersihan yang dikombinasi dengan pembangungan dan pengadaan sesuatu yang berwawasan lingkungan untuk mewujutkan prilaku hidup bersih dan sehat, serta mengadakan sarana prasarana pendukungnya.

Secara praktis ada 11 langkah gerakan Jum'at Bersih yang merupakan akronim dari Jumat bersih adalah:

$\mathrm{J}$ : jagalah jamban keluarga dan saluaran pembuangan air limbah.

$\mathrm{U}$ : usahakan semua fasilitas tetap terjaga bersih dan terpelihara dengan baik.

M : manfaatkan segala sumber daya yang ada secara efektif dan efisien.

A : adakan kerjasama terpadu baik lintas program dan lintas sektoral.

$\mathrm{T}$ : tetapkan setrategi yang harus direncanakan bersama.

B : berikan penyuluhan kesehatan kepada seluruh warga sekolah.

E : etika kerja perlu ditingkatkan secara bertanggungjawab.

$\mathrm{R}$ : rekomendasikan dan rembugkan bersama masalah kesehatan bersama.

S : setiap kegiatan harus dicatat dan dilaporkan secara rutin.

I : informasikan hasil kegiatan tersebut kepada orang lain.

$\mathrm{H}$ : hasil yang terbaik diberikan rewards.

Langkah-langkah tersebut diatas

disosialisasikan kepada seluruh warga sekolah dengan wali kelas sebagai orang yang bertanggungjawab pada wilayahnya masingmasing untuk dijadikan sebagai kawasan lingkungan yang berwawasan adiwiyata. Sedangkan program Jum'at bersih kegiatanya sebagai berikut:

5. Pengertian Aktivitas.

Aktivitas adalah merupakan prinsip atau asas dalam berintereaksi dalam proses belajar mengajar, menurut pandangan ilmu jiwa lama aktivitas dalam belajar didominasi oleh guru, sedangkan menurut ilmu jiwa mederen maka aktivitas didominasi oleh siswa, maka pergeseran budaya inilah yang di perlakukan untuk warga sekolah melaksanakan budaya lingkungan atau sekolah adiwiyata yang dicanangkan dalam KTSP dan telah didukung oleh RAPBS sebesar $20 \%$ dari seluruh anggaran sekolah, aktivitas ini didorong atau dimotivasi oleh seluruh perangkat sekolah dengan kepala sekolah sebagai penanggungjawab stekholden dengan cara melaksanakan kegiatan-kegiatan yang telah direncanakan terlebih dahulu. Dengan kegiatankegiatan inilah maka seluruh warga sekolah saling bau membau untuk beraktivitas menuju sekolah yang berwawasan lingkungan.

Aktivitas ini dapat dibagi menjadi beberapa jenis menurut Paul B. Diedric (Sudirman, 2011 : 101) diantaranya : 1) visul activities, aktivitas ini meliputi: membaca, memperhatikan gambar, demontrasi, dan memperhatikan orang lain. 2) oral activities, yang termasuk aktivitas ini adalah: menyatakan, merumuskan, bertanya, memberi saran, berpendapat, dan berdiskusi. 3) Listening activities, aktivitas ini meliputi : mendengarkan uraian, percakapan, diskusi, musik, dan pidato. 4) Writing activities, aktivitas ini meliputi : menulis cerita, karangan, laporan, dan menyalin.

Sedangkan faktor-faktor yang mempengaruhi aktivitas, antara lain: faktor internal dan faktor eksternal. Foktor internal terdiri dari : a) faktor jasmani (fisiologis) Baik Yang Bersifat Bawaan maupun yang diperoleh dari lingkungan sekitar, misalnya pendengaran, penglihatan, dan sebagainya, b) faktor psikologis baik yang bersifat bawaan maupun yang diperolehnya, terdiri dari : kecerdasan, bakat, kecakapan, kepribadian, kebiasaan, minat, kebutuhan, emosi, dan motivasi. Sedangkan faktor ekternal terdiri dari : a) faktor sosial, terdiri dari : lingkungan keluarga, lingkungan sekolah, lingkungan masyarakat, dan lingkungan kelompok, b) ilmu pengetahuan dan teknologi, c) faktor lingkungan fisik terdiri dari : fasilitas rumah, iklim, dan fasilitas belajar, d) faktor lingkungan spiritual dan keamanan.

\section{B. Hasil Penelitian yang Relevan.}

Penelitian ini telah banyak yang melakukan sebelumnya, penelitian itu diantaranya adalah :

1. Penilitian Tri Rismawati. (Jurnal Pendidikan Kewarganegaraan, vol. 2, No. 1(2013) dengan judul Penelitian : efektifitas program adiwiyata sebagai upaya penanaman rasa cinta lingkungan di SMP Negeri 3 Malang. Persamaannya adalah sama-sama menuju sekolah adiwiyata, yaitu mengelola lingkungan sekolah.

2. Sumarlin, Rini Rahmawati. (Jurnal Majalah Giografi Indonesia 2013, XXVII (1)) dengan judul : Persepsi dan kepedulian pengelolaan lingkungan sekolah melalui program 
adiwiyata. Persamaan dengan penelitian ini adalah sama-sama membangun kepedulian lingkungan menuju sekolah adiwiyata.

\section{Kerangka Berpikir.}

Dari keadaan dilapangan yaitu di SMP negeri 8, SMP Negeri 7 dan di SMP negeri
Gembong Pati. Lingkungannya perlu lebih ditingkatkan kualitasnya untuk menuju sekolah adiwiyata yang lebih tinggi. yaitu dengan dua siklus I memberi tindakan program jum'at bersih, dan siklus II juga dengan jum'at bersih yang berkelanjutan Dengan kerangka seperti dibawah ini

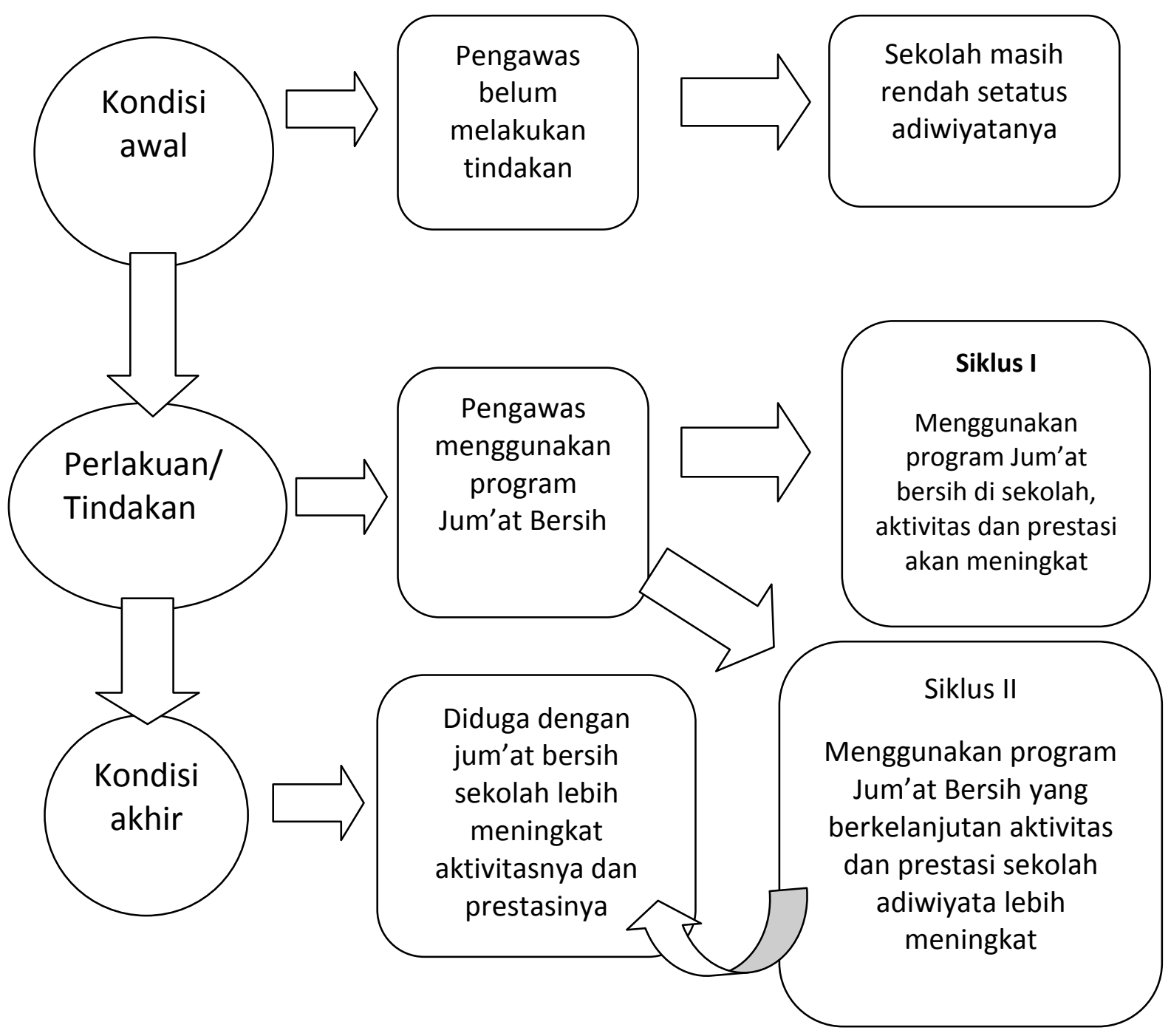

\section{Hipotesis Tindakan}

Adapaun hipotesis penelitian tindakan sekolah yang dilakukan oleh peneliti dengan Peningkatan Prestasi Menuju Sekolah Adiwiyata SMP di Kabupaten Pati:Meningkatkan aktifitas warga sekolah dengan program Jum'at Bersih untuk

\section{A. Seting Penelitian}

\section{METODOLOGI PENELITIAN}

1. Tempat penelitian

Tempat penelitian ini dilaksanakan di SMP Kabupaten Pati tepatnya di SMP Negeri 8, SMP negeri 7 dan SMP Negeri Gembong.

2. Waktu Penelitian. menuju sekolah adiwiyata atau sekolah yang berwawasan lingkungan.

Meningkatkan prestasi sekolah adiwiyata dengan program Jum'at Bersih untuk menjadi sekolah yang bepridikat adiwiyata yang lebih tinggi.

Waktu penelitian dilaksanakan pada semester ganjil yaitu pada bulan Januari sampai dengan bulan Mei

3. Subyek Penelitian.

Subyek penelitian ini adalah SMP negeri 8, SMP Negeri 7, dan SMP Negeri Gembong di Kabupaten Pati, sekolah ini dipilih karena SMP Negeri 8 sebagai sekolah di tengah kota yang telah menuju 
sekolah Adiwiyata, meskipun luas tanah yang ditempati kurang luas, SMP Negeri 7 adalah sekolah pinggiran kota yang siswanya rata-rata berasal dari limpahan dari SMP-SMP lain yang tidak diterima, sedangkan SMP Negeri Gempong adalah SMP di kecamatan yang tidak punya akses ke kecamatan lain kecuali ke kota kabupaten, sehingga bila ketiga sekolahan tersebut bila diberi tindakan dengan program Jum'at Bersih maka akan terarah aktivitasnya menuju sekolah yang berwawasan lingkungan atau sekolah adiwiyata.

\section{A. Prosedur Penelitian.}

Penelitian ini adalah penelitian tindakan sekolah, sedangkan pelaksanaanya dilakukan oleh peneliti di beberapa sekolah dengan perlakuan dan prosedur sama meskipun tempat dan anggota sekolah atau stekholdernya berbeda. Prosedur penelitianya sebagai berikut: perencanaan (planning), tindakan (acting), pengamatan (observing), dan refleksi (reflecting).

Sebelum melakukan tindakan dalam penelitian, perlu memyiapkan hal-hal yang berkaitan dengan proses penerapan program jum'at bersih dalam rangka menciptakan sekolah berwawasan linggkungan atau sekolah adiwiyata adalah :

1. Menyiapkan kegiatan apasaja yang perlu dikemas dalam program jum'at bersih.

2. Menyiapkan intrumen yang akan digunakan untuk mengevaluasi program yang sudah dilaksanakan baik alat evaluasi peningkatan dan aktivitas sekolah adiwiyata.

3. Menyiapkan sarana prasarana bersama sekolah yang akan diberi tindakan

4. Menyiapakan jadwal yang harus dilakukan dalam mencapai sekolah adiwiyata.

Sedangkan langkah-langkahnya dalam penelitian ini adalah bersifat berkelanjutan dari siklus ke siklus atau berulang-ulang sehingga akan didapatkan hasil akhir yang lebih baik. Siklus yang akan digunakan adalah dua siklus, dan masing-masing siklus terdiri dari perencanaan (planning), tindakan (acting), pengamatan (observing), dan refleksi (reflecting).

\section{Siklus I}

1. Tahap Perencanaan (planning).

Tahap ini terdiri dari :

a. Mengindentifikasi dan merumuskan masalah.

b. Merancang isi kegiatan program Jum'at Bersih. c. Merancang alat evaluasi yang akan digunakan untuk kemajuan/prestasi sekolah adiwiyata

2. Tahap Pelaksanaan (action).

Tahap pelaksanaan ini terdiri dari :

a. Peneliti melakukan pengamatan atau observasi sebagai langkah awal untuk mengetahui kondisi awal dari masingmasing sekolah untuk melakukan tindakan yang harus diberikan.

b. Menyampaikan tujuan dari program jum'at bersih agar dapat dilakukan untuk menuju prestasi sekolah yang berwawasan lingkungan atau sekolah adiwiyata.

c. Warga sekolah membentuk kelompok kader adiwiyata untuk melaksanakan tugas masing-masing yang telak disepakati bersama selain tugas pokok kerja bakti membersihkan lingkungan.

d. Setelah semua warga sekolah melaksanakan tugasnya masing-masing, peneliti, kepala sekolah dan kader adiwiyata (tim work) berkeliling untuk evaluasi sekaligus membimbing dalam melaksanakan aktivitasnya apakah sudah berjalan sesuai dengan rencana atau belum.

e. Tim evaluasi sekolah bersama sama dengan kelompok tim adiwiyata melakukan pengamatan hasil aktivitas yang telah dilaksanakan pada siklus I. yang akan tindaklanjuti pada siklus II sebagai prestasi sekolah adiwiyata atau sekolah berwawasan lingkungan.

3. Tahap Pengamatan (Observation)

a. Peneliti mengamati hasil dari aktivitas semua warga sekolah yang telah dikerjakan kelompok-kelompok tim adiwiyata sebagai hasil prestasi dari sekolah atau stekhalder masing-masing.

b. Peneliti dalam mengobservasi juga melakukan penilaian hasil dari aktivitas siklus I yang kemudian dianalisis hasil dari masing-masing sekolahan.

4. Reflektive.

Melaksanaakan analisis dari hasil aktivitas masing-masing tim adiwiyata yang telah dilaksanakan pada siklus I kemudian dilanjutkan pada siklus II seperti pada program jum'at bersih yang telah ditentukan.

\section{Siklus II.}

1. Tahap Perencanaan (planning) Tahap ini terdiri dari :

a. Mengindentifikasi dan merumuskan masalah. 
b. Merancang isi kegiatan program jum'at bersih

c. Merancang alat evaluasi yang akan digunakan untuk kemajuan/prestasi sekolah adiwiyata

2. Tahap Pelaksanaan (action)

Tahap pelaksanaan ini terdiri dari :

a. Peneliti melakukan pengamatan atau observasi sebagai langkah awal untuk mengetahui kondisi awal (siklus I) dari masing-masing sekolah untuk melakukan tindakan yang harus diberikan agar hasilnya lebih baik.

b. Menyampaikan tujuan dari program jum'at bersih kepada semua warga sekolah agar dapat dilakukan bersamasama untuk menuju prestasi sekolah yang berwawasan lingkungan atau sekolah adiwiyata yang telah ditentukan masingmasing sekolah.

c. Warga sekolah membentuk kelompok kader adiwiyata untuk melaksanakan tugas masing-masing yang telak disepakati bersama selain tugas pokok kerja bakti membersihkan lingkungan,d dan menanami pohon atau mengganti pohon yang dianggap tidak layak lagi

d. Setelah semua warga sekolah melaksanakan tugasnya masing-masing, peneliti, kepala sekolah dan kader adiwiyata (tim work) berkeliling untuk evaluasi sekaligus membimbing, dan memperbaiki dalam melaksanakan aktivitasnya apakah sudah berjalan sesuai dengan rencana atau belum untuk menuju sekolah adiwiyata yang telah disepakati bersama.

e. Tim evaluasi sekolah bersama sama dengan kelompok tim adiwiyata melakukan pengamatan hasil aktivitas yang telah dilaksanakan pada siklus I, dan siklus II sebagai prestasi sekolah adiwiyata atau sekolah berwawasan lingkungan untuk diajukan penilaian pada peneliti.

5. Tahap Pengamatan (Observation)

c. Peneliti mengamati hasil dari aktivitas semua warga sekolah yang telah dikerjakan kelompok-kelompok tim adiwiyata sebagai hasil prestasi dari sekolah atau stekhalder masing-masing.

d. Peneliti dalam mengobservasi juga melakukan penilaian hasil dari aktivitas siklus II yang kemudian dianalisis hasil dari masing-masing sekolahan sebagai hasil akhir dari penelitian ini.

6. Reflektive.
Melaksanaakan analisis dari hasil aktivitas masing-masing tim adiwiyata yang telah dilaksanakan pada siklus I dan siklus II program jum'at bersih yang telah ditentukan sebagai hasil akhir dari penelitian ini, dan sekolah dapat melanjutkan program tersebut atau program jum'at bersih agar kondisi sekolan terjaga atau terpilihara lingkungannya.

B. Metode Pengumpulan Data.

Metode pengumpulan data terdiri dari dua cara yaitu:

1. Metode dokumentasi, metode ini digunakan untuk mendapatkan data keadaan awal dari sekolah tentang budaya lingkungan sekolah tersebut sehingga peneliti mendapat gambaran yang sebenarnya tentang sekolah adiwiyata.

2. Metode pengamatan atau observasi, metode ini digunakan untuk mengamati dan mengopservasi tentang :

a. Metode pengamatan atau observasi tentang aktivitas warga sekolah tentang budaya lingkungan sekolah atau sekolah adiwiyata melalui angket yang diberikan dan diisi oleh ketua tim adiwiyata sekolah, pada akhir siklus I dan akhir siklus II. Data ini digunakan untuk mengetahui kemajuan aktivitas dari warga sekolah.

b. Metode evaluasi yang dilaksanakan pada akhir siklus I dan siklus II, data ini digunakan untuk mengetahui kemajuan prestasi sekolah adiwiyata atau sekolah yang berbudaya lingkungan pada sekolah masing-masing.

Data aktivitas warga sekolah menggunakan angket yang diisi oleh ketua tim adiwiyata baik pada awal penelitian dan akhir penelitian tetapi perlakuannya berbeda, pada awal penelitian sekolah belum mendapatkan perlakuan dengan program Jum'at Bersih tetapi pada siklus I dan siklus II sekolah sudah mendapat perlakuan program Jum'at Bersih.

Data prestasi sekolah adiwiyata menggunakan intrumen evaluasi pencapaian adiwiyata yang dikeluarkan oleh BLH. Data ini diambil pada awal penelitian dan akhir penelitian tetapi perlakuannya berbeda, pada awal penelitian sekolah belum mendapatkan perlakuan dengan program Jum'at Bersih tetapi pada siklus I dan siklus II sekolah sudah mendapat perlakuan program Jum'at Bersih. 
Data dari kedua siklus baik aktivitas warga sekolah maupun data prestasi sekolah adiwiyata dibandingkan untuk mendapatkan apakah ada perubahan atau kemajuan dari siklus I dan siklus II setelah mendapat perlakukan program Jum'at Bersih.

C. Metode Analisis Data.

Metode analisis data adalah menganalisis data yang telah diambil pada saat awal, siklus I dan siklus II, terdiri dari :

1. Metode analis data prestasi dan aktivitas sekolah adiwiyata awal merupakan diskripsi dari prestasi sekolah sebelum diadakan tindakan berupa berupa program Jum'at Bersih, data ini digunakan untuk mengetahui skor awal sebelum diadakan tindakan, sehingga dari data awal ini peneliti dapat menentukan keberhasilan dari penelitian

2. Metode analisis aktivitas warga sekolah, merupakan diskripsi dari angket yang telah diisi dari ketua tim adiwiyata sekolah, data yang dianalisis adalah data aktivitas sekolah setelah diadakan tindakan program Jum'at Bersih pada siklus I dan siklus II, dan untuk data siklus II adalah tindakan program Jum'at Bersih yang telah diperbaiki.

3. Metode analisis prestasi sekolah adiwiyata, merupakan diskripsi kualitatif dari nilai prestasi sekolah adiwiyata pada siklus I dan siklus II setelah sekolah diadakan program Jum'at Bersih, dan untuk siklus II merupakan program Jum'at Bersih yang telah diperbaiki aktivitasnya apakah ada peningkatan ataupenurunan, kemudian dicari penyebabnya dan diakhiri dengan kesimpulan dari hasil penelitian.

D. Indikator Keberhasilan.

Indikator keberhasilan dari penelitian tindakan sekolah yang diperlakukan pada sekolah yaitu: SMP Negeri 8, SMP Negeri 7, dan SMP Negeri Gembong dengan program Jum'at Bersih adalah :

1. Sekolah di kabupaten Pati, yaitu ; SMP Negeri 8, SMP Negeri 7, dan SMP Negeri Gembong aktivitas warga sekolah meningkat dari siklus I ke siklus II, setelah diperlakukan program Jum'at Bersih.

2. Sekolah di kabupaten Pati, yaitu ; SMP Negeri 8, SMP Negeri 7, dan SMP Negeri Gembong prestasi sekolah adiwiyata meningkat dari siklus I ke siklus II, setelah diperlakukan program Jum'at Bersih.

HASIL PENELITIAN DAN PEMBAHASAN

A. Diskripsi Kondisi Sekolah.

1. Diskripsi Kondisi Sekolah.

Pada awalnya peneliti mengadakan observasi di sekolah Kabupaten Pati khususnya sekolah SMP, tetapi yang peneliti pilih yaitu : SMP Negeri 8, SMP Negeri 7, dan SMP Negeri Gembong. Dari ketiga sekolah tersebut menujukan gejalan penurunan aktivitas dan prestasi, seperti data diatas tetapi setelah diberi tindakan dengan Jum'at Bersih maka didapat data sebagai berikut.

Tabel 4.1Data Aktivitas \& PrestasiSiklus I

\begin{tabular}{cccc}
\hline No & Nama Sekolah & Aktivitas & Prestasi \\
\hline 1 & SMP Negeri 8 Pati & 72,7 & 71,5 \\
2 & SMP Negeri 7 Pati & 75 & 60,75 \\
3 & SMP Negeri Gembong & 59 & 55 \\
\hline
\end{tabular}


Sedangkan pada siklus II didapatkan data sebagai berikut:

Tabel 4.2Data Aktivitas \& Prestasi Siklus II

\begin{tabular}{cccc}
\hline No & Nama Sekolah & Aktivitas & Prestasi \\
\hline 1 & SMP Negeri 8 Pati & 81 & 74,5 \\
2 & SMP Negeri 7 Pati & 79,5 & 72,25 \\
3 & SMP Negeri Gembong & 63,6 & 67,75 \\
\hline
\end{tabular}

Tabel 4.3.Hasil Aktivitas dan Prestasi Sekolah Adiwiyata

\begin{tabular}{ccccccc}
\hline Nama & \multicolumn{2}{c}{ Siklus I } & \multicolumn{2}{c}{ Siklus II } & \multicolumn{2}{c}{ Kenaikan } \\
\cline { 2 - 7 } sekolah & aktivitas & $\begin{array}{c}\text { Prestasi } \\
\text { Adiwiyata }\end{array}$ & aktivitas & $\begin{array}{c}\text { Prestasi } \\
\text { Adiwiyata }\end{array}$ & Aktivitas & $\begin{array}{c}\text { Prestasi } \\
\text { Adiwiyata }\end{array}$ \\
\hline SMP N 8 Pati & 72,7 & 71,5 & 81 & 74,5 & 8,3 & 3 \\
SMP N 7 Pati & 75 & 60,75 & 79,5 & 72,25 & 3,5 & 12,5 \\
$\begin{array}{c}\text { SMP N Gembong } \\
\text { Pati }\end{array}$ & 59 & 55 & 63,6 & 67,75 & 3,4 & 11,25 \\
\hline
\end{tabular}

Untuk lebih jelasnya dapat disajikan dengan diagram batang sebagaio berikut:

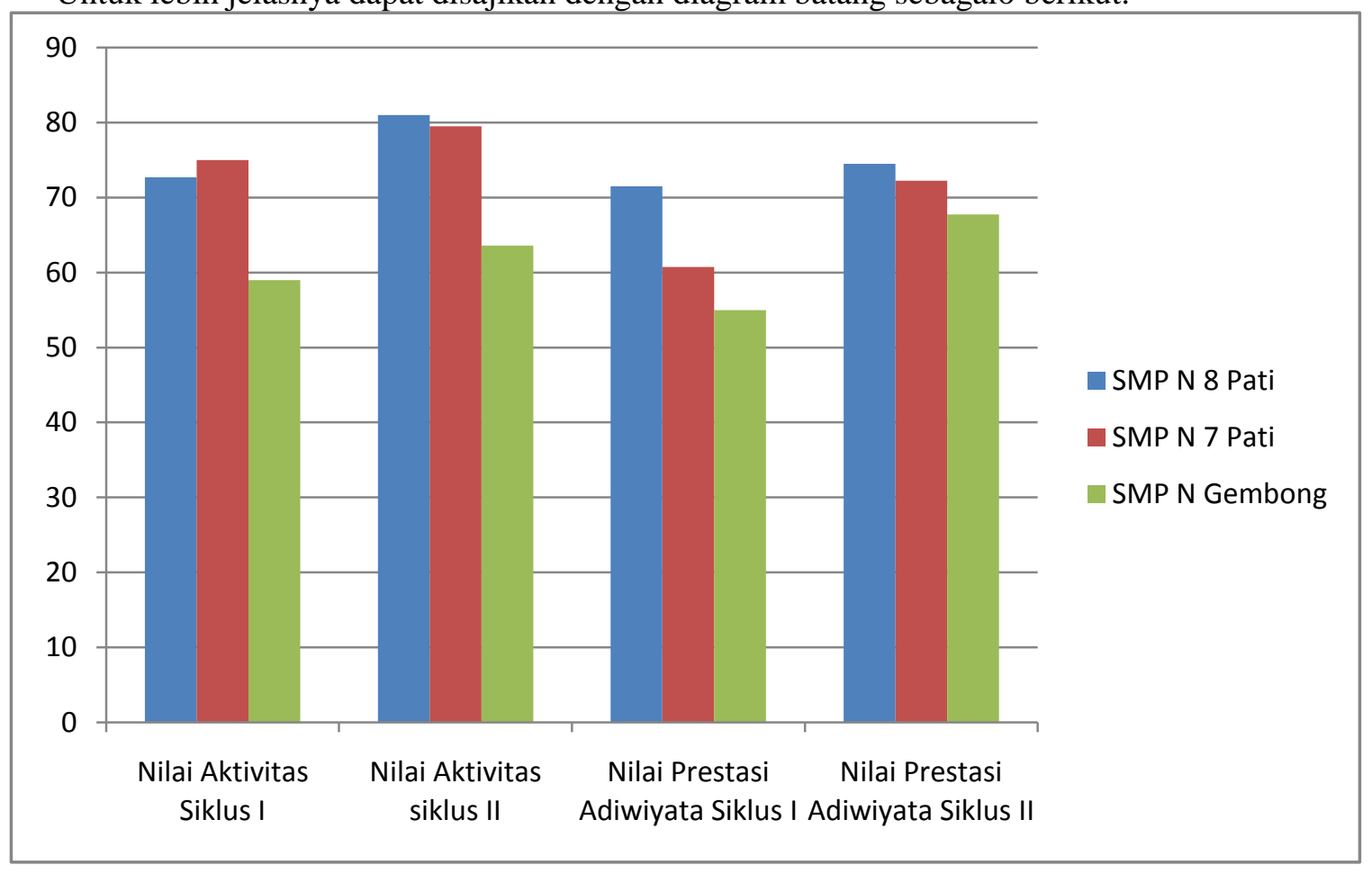

\section{A. Simpulan.}

Berdasarkan data yang telah dihimpun dari bab sebelumnya maka dapat ditarik kesimpulan sebagai berikut:

1. Aktivitas warga sekolah dalam menerapkan program jum'at bersih

c) ti mangalami kenaikan sebesar: 3,5 atau $4,6 \%$.

d) Untuk SMP Negeri Gembong Pati mengalami kenaikan sebesar: 3,4 atau $5,7 \%$.

2. Nilai prestasi sekolah adiwiyata dalam penerapan program Jum'at bersih mengalami kenaikan rata-rata sebesar: 8,91 atau $2,73 \%$

A. Saran mengalami kenaikan rata-rata sebesar: 5,06 atau $7,23 \%$.

a) Untuk SMP Negeri 8 Pati mengalami kenaikan sebesar: 8,3 atau 11,4\%.

b) Untuk SMP Negeri $7 \mathrm{~Pa}$

a) Untuk SMP Negeri 8 Pati mengalami kenaikan sebesar: 3,0 atau 4,1\%.

b) Untuk SMP Negeri 7 Pati mangalami kenaikan sebesar: 12,5 atau 2,05\%.

c) Untuk SMP Negeri Gembong Pati mengalami kenaikan sebesar: 11,25 atau $2,05 \%$. 
Setelah diketahui bahwa penerapan program Jum'at bersih untuk meningkatkan aktivitas warga sekolah dan nilai prestasi adiwiyata maka:

1. Untuk lembaga (sekolah), penelitian tindakan sekolah ini agar dapat digunakan sebagai bahan acuan untuk penanganan sekolah adiwiyata.

2. Untuk pengawas, penelitian tindakan sekolah ini program Jum'at bersih bisa
3. diterapkan kesekolah lain agar sekolahsekolah tersebut tercipta suasana yang membangun lingkungan yang bersih, rindang dan menyenangkan.

4. Untuk kepala sekolah, penelitian tindakan sekolah ini program adiwiyata dapat digunakan untuk memperbaharui pengelolaan sekolah adiwiyata.

\section{DAFTAR PUSTAKA}

Dwiyanto B, Kus. 2007. Pencemaran Lingkungan dan Penangananya, Yogyakarta: Kanisius.

Mahmud, M. Dimyati. 1989. Psikologi Pendidikan. Jakarta: Depdikbud.

Moran, Sally. 2009. Daur Ulang Sampah. Solo: Tiga Serangkai.

Neolaka, Amos. 2008. Kesadaran Lingkungan. Jakarta: Rineke Cipta.

Purwanto, Ngalim. 1990. Psikologi Pendidikan. Bandung: PT Remaja Rosda Karya.

Sastriwijaya, A. Tresna, 2009. Pencemaran Lingkungan, Jakarta: Rineke Cipta.

Suryabrata, Sumadi. 2004. Psikologi Pendidikan. Jakarta: Raja Grafindo Persda.

CMS, 2011.Aquaponik. CMS Made Simple. Aquaponik. Htm. Diakses 5 Juli 2011

Deustche Welle Indonesia, 2009.Pertanian Aquaponik Modern.Sains dan Teknologi Deustche 
